\title{
Is human immunodeficiency virus/acquired immunodeficiency syndrome decreasing among Brazilian injection drug users? Recent findings and how to interpret them
}

\author{
Francisco I Bastos/+ , Vera Bongertz*, Sylvia Lopes Teixeira*, Mariza G Morgado*, \\ Mariana A Hacker
}

Departamento de Informação em Saúde, CICT-Fiocruz, Av. Brasil 4365, 21045-900, Rio de Janeiro, RJ, Brasil *Departamento de Imunologia, IOC-Fiocruz, Rio de Janeiro, RJ, Brasil

We briefly review findings from Brazilian settings where the human immunodeficiency virus/acquired immunodeficiency syndrome (HIV/AIDS) epidemic among injection drug users (IDUs) seems to be decreasing, highlighting recent findings from Rio de Janeiro and discussing methodological alternatives. Former analyses using serologic testing algorithm for recent HIV seroconversion have shown that HIV incidence has been low in IDUs recruited by two different surveys carried out in Rio, where low injection frequencies and infection rates have been found among new injectors. The proportion of AIDS cases among IDUs in Rio has been fairly modest, compared to São Paulo and especially to the southernmost states.

Notwithstanding, the interpretation of findings from serial surveys constitutes a challenge, magnified in the assessment of HIV spread among IDUs due to the dynamic nature of the drug scenes and limitations of sampling strategies targeting hard-to-reach populations. Assessment of epidemic trends may profit from the triangulation of data, but cannot avert biases associated with sampling errors. Efforts should be made to triangulate data from different sources, besides exploring specific studies from different perspectives. In an attempt to further assess the observed trends, we carried out original analyses using data from Brazilian AIDS databank.

Key words: acquired immunodeficiency syndrome - human immunodeficiency virus - injection drug users serial serosurveys - Brazil

Injection drug users (IDUs) have had a key role in the spread of human immunodeficiency virus (HIV) and other blood-borne infections worldwide (UNAIDS 2003). Double exposed to parenterally and sexually-transmitted pathogens due to non-hygienic injection practices and to risky sex behaviors, IDUs have faced a serious burden of different infections, frequently associated with other hazards (e.g. overdose and embolism), and premature deaths (Contoreggi et al. 1998). The strongly interactive nature of their social networks, the high background infection rates of such networks and their frequent overlapping with other risk networks of marginalized and hard-to-reach populations, such as people involved in drug traffic and impoverished commercial sex workers (Kottiri et al. 2002, Friedman et al. 2003), have made IDUs a key element of rapidly spreading and extensive epidemics (Rhodes et al. 1999, 2003).

More than two decades after the emergence of the acquired immunodeficiency syndrome (AIDS) epidemic, prevention of IDUs-driven HIV/AIDS epidemics has been a chronicle of both failures and major achievements. Among the former ones, one should mention the unabated spread of HIV in Russia and the former USSR Republics (Rhodes et al. 1999, 2002, 2003). Among the successful

+Corresponding author. E-mail:bastos@ cict.fiocruz.br Received 7 July 2004

Accepted 2 December 2004 interventions, averted epidemics (Des Jarlais et al. 1995) and the recent reversion of huge AIDS epidemics, due to saturation and concerted prevention efforts, such as observed in the New York epidemic (Des Jarlais et al. 2000), should be highlighted.

With a unique drug scene, where the injection of heroin and opiates has been negligible and cocaine has been extensively snorted, smoked and, in a lesser extent, injected (Dunn \& Laranjeira 1999), Brazil is nowadays the developing country with the most comprehensive network of facilities aiming to prevent drug-related harm (Mesquita et al. 2003). On the other hand, studies targeting IDUs are still scarce in Brazil and evaluation of ongoing programs and projects aiming to reduce drug-related harm even rarer.

The present paper briefly reviews findings from Brazilian settings where the HIV/AIDS epidemic seems to be declining, highlighting recent findings from Rio de Janeiro, and discusses methodological challenges and recent developments.

Assessing drug injecting scenes: challenges and alternatives

HIV seroincidence studies have never been carried out in the drug injecting population in Brazil. With the sole exception of some applications of mathematical modeling (Massad et al. 1994), analyses of the epidemic trends in Brazilian IDUs have been entirely dependent on serial cross-sectional surveys (Mesquita et al. 2001) and data from major Brazilian databanks, such as the Brazilian Ministry of Health National AIDS Notification System 
(SINAN-AIDS) (Szwarcwald et al. 1998).

The interpretation of serial HIV seroprevalence studies constitutes a major challenge of contemporary epidemiology (Ades 1995). The difficulties are magnified due to the dynamic nature of the drug scenes and the impact of drug availability and composition on drug-using habits (Ciccarone \& Bourgois 2003) and the limitations of sampling strategies to assess hard-to-reach populations, with stigmatized and criminalized habits such as the habit of consuming, particularly injecting, illicit drugs (see Heckatorn 1997, for a discussion of different sampling methods).

One of the contemporary strategies to (partially) circumvent the abovementioned complexities and methodological limitations is to integrate information from different sources, obtained by different methods, profiting from biological, epidemiologic, and sociobehavioral data, using either quantitative and qualitative methods (Normand et al. 2003).

Using data from Brazilian studies, peer-reviewed papers and abstracts, we integrate biological findings from serological analyses of HIV and viral hepatitis, HIV incidence estimation through the use of STAHRS (serologic testing algorithm for recent HIV seroconversion; Janssen et al. 1998), and behavioral and epidemiologic data from recent surveys carried out in 1994-6 (Telles et al. 1997, Guimarães et al. 2001) and 1999-2001 (Teixeira et al. 2004, Hacker et al. 2005). Both surveys recruited patients from the Rio de Janeiro drug scene, using a targeted sampling strategy (Watters \& Biernacki 1989).

In an attempt to further triangulate data from different sources, we carried out original analyses on AIDS cases, using data from SINAN-AIDS. Data were compiled using SAS v8.2, creating a data archive for all Brazilian states, 1984-2000. Data for 2001/2002 were excluded due to reporting delays (Barbosa \& Struchiner 2002). Findings reported here refer to data, registered by place of residence, for individuals aged 15-54. We calculated the proportion of AIDS cases classified as belonging to "injection drug users" exposure category to the total number of AIDS cases for three Brazilian states (São Paulo, Rio de Janeiro, and Santa Catarina). The definition of "injection drug user" follows the hierarchical classification proposed by UNAIDS, where IDUs, even included in additional exposure categories, are classified under the broad category "injection drug users".

\section{Recent findings from Brazilian studies}

In three different Brazilian cities (Rio de Janeiro, Salvador, and Santos), with mature epidemics (Carvalho et al. 1996, Telles et al. 1997, Andrade et al. 1998, Guimarães et al. 2001, Mesquita et al. 2001) and well-established preventive programs (Telles 1999, Andrade et al. 2001, Mesquita et al. 2003), declining HIV/AIDS epidemics have been reported in the population of injection drug users.

A key question, given the considerable complexity of local drug scenes and respective patterns of HIV spread, is the extent observed declines represent actual declines.

Fig. 1 depicts a simplified representation of what may take place in a hypothetical drug injecting scene, assessed by two cross-sectional surveys, A and B. What in fact is being contrasted? Considering samples representative of the universe of IDUs from each setting (an overoptimistic assumption, as discussed later), when prevalences for HIV for those interviewees recruited in A and B are compared is a mix of: (a) the "stable" fraction surveyed by each assessment round (i.e. prevalent cases assessed by the two surveys - A1 and B1); and (b) the variable fraction of people leaving (gray rectangles in the left side of the picture) and entering (gray rectangles on the right) the setting.

Besides the usual difficulties of interpreting serial seroprevalence studies (Ades 1995), two drawbacks are specific of any hypothetical drug scene. First of all, people can drop the scene not only due to the fact they recover, move out or die as in the basic SEIR multi-compartment
A

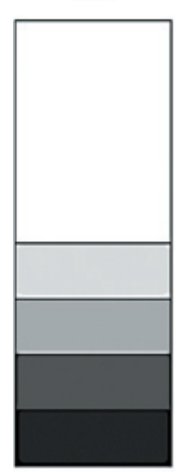

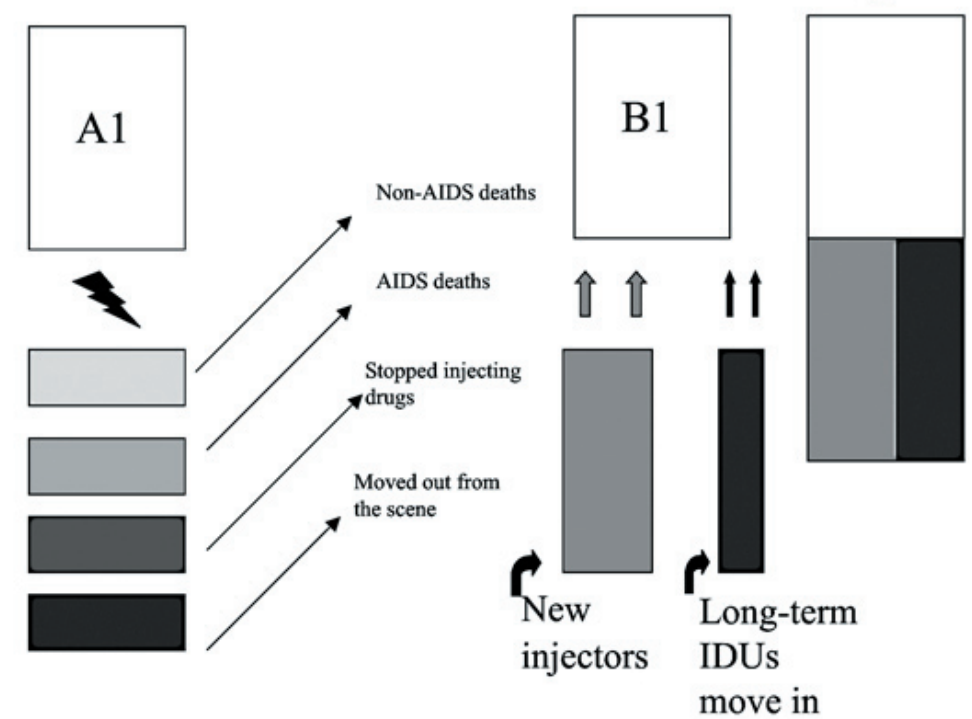

Fig 1: diagram illustrating serial assessment of the drug injecting scene 
models (Anderson \& May 1992), but due to the fact they stop injecting drugs (moving toward abstinence or the exclusive use of drugs by other routes).

In a recent paper, Caiaffa et al. (2003a) explore the contrasting HIV dynamics in two southern Brazilian cities: Itajaí (Santa Catarina) and Porto Alegre (Rio Grande do Sul). Age-structure modifications as well as major changes in the duration of injection use suggest differential turnovers of the IDUs recruited in those settings.

Whereas a deep understanding of the "transition in the routes of drug use" (Strang et al. 1992) can be only explored by longitudinal studies, analyses from surveys from both Salvador, BA (Andrade et al. 2001) and Santos, SP (Mesquita et al. 2001), attribute part of the observed decline of HIV infection rates among local IDUs to major changes of the respective drug scenes and drug-consuming habits along the years. In both settings, the very habit of injecting cocaine seemed to have been supplanted by crack cocaine smoking, either alone (i.e. consumers are no longer injection drug users, and so have left the pool of injection drug users) or establishing a new blend of drug consuming routes (most of the times with a substantial decline of injection frequencies).

The second limitation of any study carried out in the so-called "hidden populations" - sampling bias - will be addressed below.

Considering the abovementioned limitations, the research team from Rio de Janeiro has tried to enrich interpretation of trends through the use of combined data for HIV and viral hepatitis, assessing hepatitis B incidence (using HBsAg as a proxi for acute hepatitis) and estimating HIV incidence through the use of STAHRS.

As depicted in Fig. 2, both hepatitis B and C seroprevalences, especially the latter, declined substantially from the first (1994-1996) to the second serosurvey (19992001), in parallel with the observed decline of HIV prevalence, from 25.0\% (Telles et al. 1997, Guimarães et al. 2001) to $7.9 \%$ (Teixeira et al. 2004, Hacker et al. 2005). "Acute" $\mathrm{HBV}$ infection rates have been low, further declining from the first to the second study.

Consistently, former analyses using STAHRS have shown that incidence has been quite low in injection drug users assessed by both surveys carried out in Rio de Janeiro, with person-years HIV seroincidence estimated

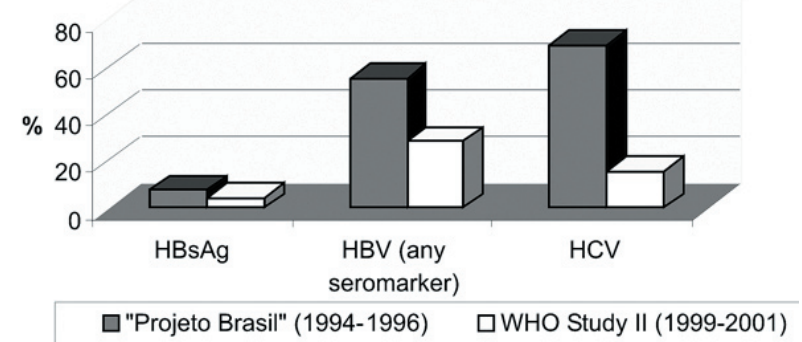

Sources: Oliveira et al. 1999, Alberti et al. 20001

Fig 2: hepatitis B virus "incidence" ( $\mathrm{HBsAg}$ ) and prevalence (any seromarker) and hepatitis $\mathrm{C}$ virus (HCV) prevalence among injection drug users recruited by two cross-sectional studies. Rio de Janeiro, 1994-1996; 1999-2001. as $0-1$ seroincident case/100 persons-year (Guimarães et al. 2001, Teixeira et al. 2004).

Additional analyses have addressed the behaviors and infection rates of new injectors (depicted in Fig. 1 as a rectangle on the right side). New injectors represent the main source of susceptibles in a context where mortality rates are quite high, both due to HIV and other infections, as well as to a myriad of other causes, such as violence and overdoses (Galai et al. 2003).

Findings from a paper addressing behaviors and infection rates of new injectors from Rio de Janeiro, recruited by the most recent survey (1999-2001) (Hacker et al. 2005) have shown that new injectors (defined as those individuals injecting for less than 6 years) have much lower injection frequencies and much lower infection rates for $\mathrm{HIV}, \mathrm{HBV}$ and $\mathrm{HCV}$, than long-term injectors.

Low prevalence for $\mathrm{HCV}$ is especially relevant since $\mathrm{HCV}$ infection is a good proxi of parenteral exposure (Burattini et al. 2000) and tends to occur very early (a few months) in the drug injecting career (Garfein et al. 1996). A recent presentation by Lopes et al. (2004) has documented high prevalence rates of HCV (approximately $40 \%$ ) among Brazilian "new injectors" (defined by the authors as "new initiators", comprising those injecting for less than 3 years) in settings where the spread of HIV and other bloodborne and sexually transmitted infections has been far from being curbed in recent years (e.g. cities located in Brazilian southernmost states, Santa Catarina and Rio Grande do Sul).

Further corroborating our findings, we found that unprotected sexual intercourse of male injectors with other men was the sole independent predictor of HIV infection among new injectors. On the other hand, among longterm injectors variables associated with shared injection were found to be the key risk factors for HIV infection (Hacker et al. 2005).

Unlike Porto Alegre (RS) (Caiaffa et al. 2003b), no study aiming to estimate the number of injection drug users has been carried out in Rio de Janeiro so far. Our own strenuous, 2 years-long, efforts to recruit in the last survey 609 injectors, exploring the most different settings with a team of community outreach workers, as well as former studies carried out in Rio de Janeiro drug treatment centers (Bastos et al. 2000), suggest that the population of IDUs from Rio de Janeiro is relatively small and pales in comparison with the large population of IDUs from Brazil's southernmost states (Bastos et al. 2002).

Reported AIDS cases, especially in the Brazilian context of universal access to anti-retroviral therapy (where case report should be a precondition of enrollment in lifesaving treatment at no cost at the point of delivery), represent essential information to the long-term assessment of epidemic trends, if one takes into account the long incubation period and reporting delays (Barbosa \& Struchiner 2002).

The scope of the epidemic among IDUs from different Brazilian settings vis-à-vis the scope of the epidemic among other vulnerable populations was assessed through the calculation of the proportion of AIDS cases reported in IDUs to the total number of AIDS cases in three Brazilian states. Exploratory analyses have shown 
there are no relevant differences between these Brazilian states respecting other at-risk populations, such as gay men and women who acquired HIV infection through unprotected heterosexual intercourse (data not shown).

As depicted in Fig. 3, the proportion of cases among IDUs in Rio de Janeiro (compared to all AIDS cases reported in each setting) has been fairly modest, compared to São Paulo and especially to the southernmost states, e.g. some municipalities from Santa Catarina, where AIDS cases reported among IDUs roughly corresponded to 50\% of all AIDS cases reported in 1994 (Caiaffa et al. 2003b). After 1997, the proportion of AIDS cases in IDUs from Rio de Janeiro has been further declining, corresponding to less than $4 \%$ of all AIDS cases in recent years.

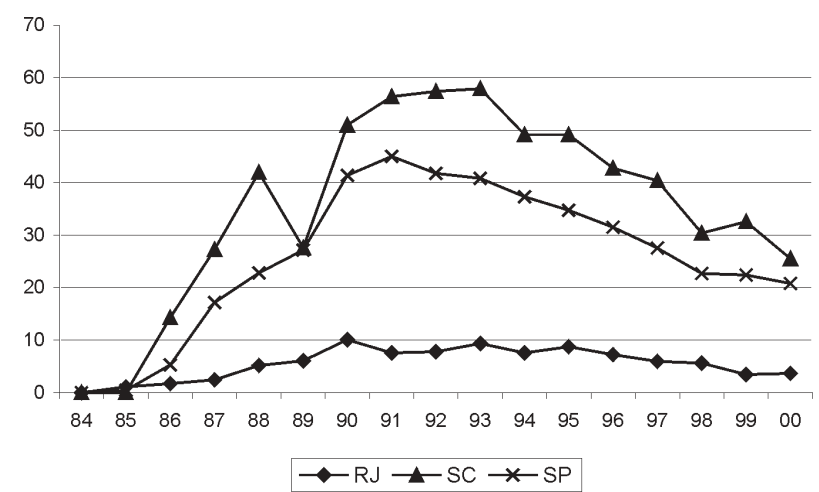

Fig. 3: number of acquired immunodeficiency syndrome (AIDS) cases (ages 15 to 54 years) registered in "injection drug users" to the total number of AIDS cases in Rio de Janeiro (RJ), São Paulo (SP), and Santa Catarina (SC), Brazil, 1984-2000.

\section{DISCUSSION}

Although assessment of epidemic trends may profit from the triangulation of data from different sources, such triangulation cannot avert the biases associated with systematic sampling errors. All efforts should be made to triangulate data from different sources, besides exploring specific studies from different perspectives.

The main alternatives to address such limitations are as follows:

1. Efforts to improve the methodological soundness of the sampling strategy, either refining targeted sampling methods, such as the respondent-driven method proposed by Heckathorn (1997), or, alternatively, using a two-step random sampling strategy, departing from a comprehensive sample, such as those from large household surveys. A comprehensive household survey was recently implemented in Brazil (Galduróz et al. 2000). Whereas very useful for other purposes, the overall prevalence of drug injection was found to be extremely low in this survey, precluding further analyses of this specific population (Galduróz et al. 2000);

2. To triangulate data from a given survey with a second, parallel, independent survey, or with an independent qualitative study. The latter alternative has been piloted in Brazil by Mesquita and coworkers (2000);
3. To comprehensively map the local drug scene, simultaneously recruiting from multiple (overlapping) sources, using log-linear models to explore data-dependence structure (Frischer et al. 1993).

Although much has to be done in Rio de Janeiro, the analyses developed so far represent an undeniable advance toward a better understanding of the local dynamics of HIV and other blood-borne infections in the population of injection drug users.

Even considering the abovementioned limitations, we will dare to advance here some hypotheses to explain the observed decline.

First of all, we should consider that a relative small population deeply affected by deadly infections for decades is likely to saturate, so continuous increase or (apparent) stabilization with persistent high infection rates are unlikely to occur. The underlying dynamics of a sustained high-prevalence high-incidence epidemic must include a permanent inflow of a large contingent of new injectors entering the drug scene at each moment. But the mere entrance in the drug scene does not translate into effective risk if the background prevalence is declining and the new injectors are rarely exposed to pathogens transmitted by non-hygienic injections practices, i.e. if new injectors minimize their injection frequencies or engage mostly in safer injection practices (never sharing and/or cleaning efficiently their injection equipment).

Different scenarios have been observed in settings with averted and declining HIV epidemics, world wide.

In San Francisco, US, considerable overlapping of different vulnerable populations has been reported, highlighting the fundamental role of unprotected sex in new injectors who have changed in a considerable extent their injecting behaviors toward safer practices (Blutenthal et al. 2001). A similar overlapping may be taking place among new injectors from Rio de Janeiro.

In Australian cities, HIV (but not HCV) low incidence and prevalence have been maintained by a combination of diminishing (but not absent) risky injection practices and unsafe sex. In Australia, HIV prevention has been considered a paradigm of efficient, coordinated and timely intervention, characterizing one of the contexts where the epidemic among IDUs was "prevented" (Des Jarlais et al. 1995). However, even such a paradigmatic set of interventions still requires further improvement to effectively curb $\mathrm{HCV}$ spread, due to the higher background prevalence of $\mathrm{HCV}$ (in mature epidemics) and putative greater transmission efficacy of HCV vis-à-vis HIV (Dore et al. 2003).

As suggested by Australian data (Dore et al. 2003), $\mathrm{HCV}$ prevalence is unlikely to stabilize at/decline to levels as low as those observed in Rio de Janeiro without behavioral change toward safer injection practices. Besides saturation, behavioral change should be considered in Rio de Janeiro, either due to spontaneous behavior change, prevention or a synergy of these factors. International literature has convincingly shown that injection drug users may benefit from different preventive strategies (Bastos \& Strathdee 2000) and many times exhibit altruistic behavior and muster their forces toward safer behaviors and less disorganized lifestyles (Des Jarlais et al. 2004). We may be observing in Rio de Janeiro a favor- 
able interaction of behavioral changes toward safer behaviors, much probably fostered by mass media preventive campaigns and word of mouth diffusion of safer habits and directly supported by preventive programs.

Auspicious findings from Rio de Janeiro, yet to be corroborated, should not be viewed with complacency, either from the methodological or practical point of view of programs aiming to reduce drug-related harm and to treat drug use. Recent methodological developments should be attempted in our setting and a genuine culture of program evaluation should be stimulated by all means in the Brazilian context.

\section{REFERENCES}

Ades AE 1995. Serial HIV seroprevalence surveys: interpretation, design, and role in HIV/AIDS prediction. J Acquir Immune Defic Syndr Hum Retrovirol 9: 490-499.

Alberti S, Hacker M, Custodio Miguel J, Oliveira ML, Bastos FI 2001. Can viral hepatitis be kept under control among injection drug users? Lessons from the field, in Rio de Janeiro, Brazil. Virus Rev Res 6: 109.

Anderson RM, May RM 1992. Infectious Diseases of Humans: Dynamics and Control, Oxford Press, Oxford, p. 768 pp.

Andrade TM, Dourado I, Galvao-Castro B 1998. Associations among HTLV-I, HTLV-II, and HIV in injecting drug users in Salvador, Brazil. J Acquir Immune Defic Syndr Hum Retrovirol 18: 186-187.

Andrade TM, Lurie P, Medina MG, Anderson K, Dourado I 2001. The opening of South America's first Needle Exchange Program and an epidemic of crack use in Salvador, BahiaBrazil. AIDS \& Behavior 5: 51-64.

Barbosa MT, Struchiner CJ 2002. The estimated magnitude of AIDS in Brazil: a delay correction applied to cases with lost dates. Cad Saúde Publica 18: 279-285.

Bastos FI, Strathdee SA 2000. Evaluating effectiveness of syringe exchange programmes: current issues and future prospects. Soc Sci Med 51: 1771-1782.

Bastos FI, Lowndes CM, Castello-Branco LR, Linhares-deCarvalho MI, Oelemann W, Bernier F, Morgado MG, Yoshida CF, Rozental T, Alary M 2000. Sexual behaviour and infection rates for HIV, blood-borne and sexually transmitted infections among patients attending drug treatment centres in Rio de Janeiro, Brazil. Int J STD AIDS 11: 383392.

Bastos FI, Pina MF, Szwarcwald CL 2002. The social geography of HIV/AIDS among injection drug users in Brazil. Int J Drug Polic 13: 137-144.

Bluthenthal RN, Kral AH, Gee L, Lorvick J, Moore L, Seal K, Edlin BR 2001. Trends in HIV seroprevalence and risk among gay and bisexual men who inject drugs in San Francisco, 1988 to 2000. J Acquir Immune Defic Syndr 28: 264-269.

Burattini M, Massad E, Rozman M, Azevedo R, Carvalho H 2000. Correlation between HIV and HCV in Brazilian prisoners: evidence for parenteral transmission inside prison. Rev Saúde Pública 34: 431-436.

Caiaffa WT, Mingoti SA, Proietti FA, Carneiro-Proietti AB, Silva RC, Lopes AC, Doneda D 2003b. Estimation of the number of injecting drug users attending an outreach syringe-exchange program and infection with human immuno- deficiency virus (HIV) and hepatitis C virus: the AjUDEBrasil project. J Urban Health 80:106-114

Caiaffa WT, Proietti FA, Carneiro-Proietti AB, Mingoti SA, Doneda D, Gandolfi D, Reis AC; Epidemiological Study of Injection Drug Users in Brazil (AjUDE-Brasil Project). 2003a. The dynamics of the human immunodeficiency virus epidemics in the South of Brazil: increasing role of injection drug users. Clin Infect Dis 37 (Suppl. 5): S376-81.

Carvalho HB, Mesquita F, Massad E, Bueno RC, Lopes GT, Ruiz MA, Burattini MN 1996. HIV and infections of similar transmission patterns in a drug injectors community of Santos, Brazil. J Acquir Immune Defic Syndr Hum Retrovirol 12: 84-92.

Ciccarone D, Bourgois P 2003. Explaining the geographical variation of HIV among injection drug users in the United States. Subst Use Misuse 38: 2049-2063.

Contoreggi C, Rexroad VE, Lange WR 1998. Current management of infectious complications in the injecting drug user. J Subst Abuse Treat 15: 95-106.

Des Jarlais DC, Hagan H, Friedman SR, Friedmann P, Goldberg D, Frischer M, Green S, Tunving K, Ljungberg B, Wodak A et al. 1995. Maintaining low HIV seroprevalence in populations of injecting drug users. JAMA 274: 1226-1231.

Des Jarlais DC, Marmor M, Friedmann P, Titus S, Aviles E, Deren S, Torian L, Glebatis D, Murrill C, Monterroso E, Friedman SR 2000. HIV incidence among injection drug users in New York City, 1992-1997: evidence for a declining epidemic. Am J Public Health 90: 352-359.

Des Jarlais DC, Perlis T, Arasteh K, Hagan H, Milliken J, Braine N, Yancovitz S, Mildvan D, Perlman DC, Maslow C, Friedman SR 2004. "informed altruism" and "partner restriction" in the reduction of HIV infection in injecting drug users entering detoxification treatment in new york city, 1990-2001. J Acquir Immune Defic Syndr 35: 158-166

Dore GJ, Law M, MacDonald M, Kaldor JM 2003. Epidemiology of hepatitis C virus infection in Australia. J Clin Virol 26: 171-184.

Dunn J, Laranjeira R 1999. Cocaine-profiles, drug histories, and patterns of use of patients from Brazil. Subst Use Misuse 34: 1527-1548.

Friedman SR, Flom PL, Kottiri BJ, Zenilman J, Curtis R, Neaigus A, Sandoval M, Quinn T, Des Jarlais DC 2003. Drug use patterns and infection with sexually transmissible agents among young adults in a high-risk neighbourhood in New York City. Addiction 98: 159-169.

Frischer M, Leyland A, Cormack R, Goldberg DJ, Bloor M, Green ST, Taylor A, Covell R, McKeganey N, Platt S 1993. Estimating the population prevalence of injection drug use and infection with human immunodeficiency virus among injection drug users in Glasgow, Scotland. Am J Epidemiol 138: $170-181$.

Galai N, Safaeian M, Vlahov D, Bolotin A, Celentano DD 2003. ALIVE Study. Longitudinal patterns of drug injection behavior in the ALIVE Study cohort, 1988-2000: description and determinants. Am J Epidemiol 158: 695-704.

Galduróz JCF, Noto AR, Nappo SA, Carlini EA 2000. I Levantamento Domiciliar Nacional sobre o Uso de Drogas Psicotrópicas. Parte A: Estudo Envolvendo as 24 Maiores Cidades do Estado de São Paulo, 1999. Centro Brasileiro 
de Informações sobre Drogas Psicotrópicas, Universidade Federal de São Paulo, 135 pp.

Garfein RS, Vlahov D, Galai N, Doherty MC, Nelson KE 1996. Viral infections in short-term injection drug users: the prevalence of the hepatitis $\mathrm{C}$, hepatitis $\mathrm{B}$, human immunodeficiency, and human T-lymphotropic viruses. Am J Public Health 86: 655-661.

Guimarães ML, Bastos FI, Telles PR, Galvão-Castro B, Diaz RS, Bongertz V, Morgado MG 2001. Retrovirus infections in a sample of injecting drug users in Rio de Janeiro City, Brazil: prevalence of HIV-1 subtypes, and co-infection with HTLV-I/II. J Clin Virol 21: 143-151.

Hacker MA, Friedman SR, Telles PR, Teixeira SL, Bongertz V, Morgado MG, Bastos FI 2005. The role of "long-term" and "new injectors" in a declining HIV/AIDS epidemic in Rio de Janeiro, Brazil. Subst Use Misuse 40: 1-31.

Heckathorn DD 1997. Respondent-driven sampling: a new approach to the study of hidden populations. Soc Probl 44: 174-199.

Janssen RS, Satten GA, Stramer SL, Rawal BD, O'Brien TR, Weiblen BJ, Hecht FM, Jack N, Cleghorn FR, Kahn JO, Chesney MA, Busch MP 1998. New testing strategy todetect early HIV-1 infection for use in incidence estimates and for clinical and prevention purposes. JAMA 280: 42-48.

Kottiri BJ, Friedman SR, Neaigus A, Curtis R, Des Jarlais DC 2002. Risk networks and racial/ethnic differences in the prevalence of HIV infection among injection drug users. J Acquir Immune Defic Syndr 30: 95-104

Lopes ACS, Caiaffa WT, Mingoti AS, AAjUDE-Brasil II Project 2004. Prevention of HIV infection in new initiators streetrecruited injection drug users (IDUs). Proc XV Int AIDS Conference, Bangkok.

Massad E, Coutinho FA, Yang HM, De Carvalho HB, Mesquita F, Burattini MN 1994. The basic reproduction ratio of HIV among intravenous drug users. Math Biosci 123: 227-247.

Mesquita F, Kral A, Reingold A, Bueno R, Trigueiros D, Araujo PJ, Santos Metropolitan Region Collaborative Study Group 2001. Trends of HIV infection among injection drug users in Brazil in the 1990s: the impact of changes in patterns of drug use. J Acquir Immune Defic Syndr 28: 298-302.

Mesquita F, Bueno R, Araujo PJ, Piconez D, Turienzo L G, Haddad IM 2000. Rapidly responding to injecting drug use and HIV in Brazil: a field-report from Sao Vicente, São Paulo State. Int J Drug Policy 11: 133-144.

Mesquita F, Doneda D, Gandolfi D, Nemes MI, Andrade T, Bueno R, Piconez e Trigueiros D 2003. Brazilian response to the human immunodeficiency virus/acquired immunodeficiency syndrome epidemic among injection drug users.
Clin Infect Dis 37: 382-385.

Normand JL, Lambert EY, Vlahov D 2003. Understanding the dynamics of sexual transmission of HIV among drug-using populations: an integration of biological, behavioral, and environmental perspectives. J Urban Health 80: III1-III6.

Oliveira ML, Bastos FI, Telles PR, Yoshida CF, Schatzmayr HG, Paetzold U, Pauli G, Schreier E 1999. Prevalence and risk factors for $\mathrm{HBV}, \mathrm{HCV}$, and $\mathrm{HDV}$ infections among injecting drug users from Rio de Janeiro, Brazil. Braz J Med Biol Res 32: 1107-1114.

Rhodes T, Stimson GV, Crofts N, Ball A, Dehne K, Khodakevich L 1999. Drug injecting, rapid HIV spread, and the 'risk environment': implications for assessment and response. AIDS 13: 259-269.

Rhodes T, Lowndes C, Judd A, Mikhailova LA, Sarang A, Rylkov A, Tichonov M, Lewis K, Ulyanova N, Alpatova T, Karavashkin V, Khutorskoy M, Hickman M, Parry JV, Renton A 2002. Explosive spread and high prevalence of HIV infection among injecting drug users in Togliatti City, Russia. AIDS 16: 25-31.

Rhodes T, Mikhailova L, Sarang A, Lowndes CM, Rylkov A, Khutorskoy M, Renton A 2003. Situational factors influencing drug injecting, risk reduction and syringe exchange in Togliatti City, Russian Federation: a qualitative study of micro risk environment. Soc Sci Med 57: 39-54.

Strang J, Des Jarlais DC, Griffiths P, Gossop M 1992. The study of transitions in the route of drug use: the route from one route to another. Br J Addict 87: 473-483.

Szwarcwald C, Bastos FI, de Castilho EA 1998. The dynamics of the AIDS epidemic in Brazil: a space-time analysis in the period 1987-1995. Braz J Infect Dis 2: 175-186.

Telles PR 1999. Preventing HIV/AIDS and other sexually transmitted diseases among injecting drug users in Rio de Janeiro. Int J Drug Polic 10: 365-373.

Telles PR, Bastos FI, Guydish J, Inciardi JA, Surratt HL, Pearl M, Hearst N 1997. Risk behavior and HIV seroprevalence among injecting drug users in Rio de Janeiro, Brazil. AIDS 11: $35-42$.

Teixeira SLM, Bastos FI, Telles PR, Hacker MA, Brigido LF, Oliveira CAF, Bongertz V, Morgado MG 2004. HIV-1 infection among injection and ex-injection drug users from Rio de Janeiro, Brazil: prevalence, estimated incidence and genetic diversity. J Clin Virol 31: 221-226.

UNAIDS 2003. AIDS Epidemic Update 2003. UNAIDS, 300 pp.

Watters JK, Biernacki P 1989. Targeted sampling-options for the study of hidden populations. Soc Prob 36: 416-430. 